\title{
「素材・技術＼cjkstart東海支部の総合紹介講演会から」 特集号の企画にあたって
}

ゴム・エラストマーは，社会生活を支える材料 として多くの工業製品に使用されています。高機 能化の要求に応えるために, 現在も多くの企業で ゴム・エラストマーおよびそれに関連した製品の 開発が進められ，新しい技術や商品が世に送り出 されています。そこで, 先日の6月号では,「新技術・ 新素材 関東支部・関西支部の総合紹介講演会か ら」と題した特集号を企画し，関東支部および関 西支部における総合紹介講演会で紹介された技術 や製品を取り上げて会員の皆様にお届けしました. 引き続き今回の 8 月号でも，東海支部で開催され た総合紹介講演会の中から, 高機能なエラスト マー・ゴム製品を支える新たな素材に焦点を当て， 紹介することにしました。

はじめに,「高機能オレフィン系熱可塑性エラス トマーJSR EXCELINK ${ }^{\circledR} の こ ゙$ 紹介」と題して, 独 自のポリマーアロイ化技術とコンパウンド化技術 を融合したオレフィン系熱可塑性エラストマー材 料が紹介されています。加硫ゴムと比べてリサイ クルが容易な環境配慮型材料としての特徵とその 応用例が述べられています。

「新規高耐熱アクリル系ゴム（デンカ $\mathrm{ER}^{\circledR} \mathrm{ERX}-$ 219）の開発」では，アクリルゴムの基本的な構造 と物性との関係および熱劣化機構が簡単に解説さ れ，この熱劣化を抑えられる高耐熱アクリル系ゴ ムについて述べられています。このゴム材料では カルボキシル架橋タイプが採用され, 従来品に比 べて優れた耐熱性を示すことが紹介されています。

次にクロロスルホン化ポリエチレン (CSM) や フッ素ゴム $(\mathrm{FKM})$ の高機能化に関して,「液状 1,2エポキシ化ポリブタジエンによる CSMやFKMへ
の添加効果」を紹介します，CSM やFKMを用い た製品では受酸剤としてPbOを使いますが，鉛規 制で $\mathrm{MgO}$ などへの代替が進んでいます。この受酸 剂にエポキシ化液状ポリブタジエンを使用すると $\mathrm{MgO}$ で問題となる耐酸性や耐水性が改善されるば かりか, 機械的強度や耐引裂性も向上することが 紹介されています。

続いて紹介するのは,「単層カーボンナノチュー

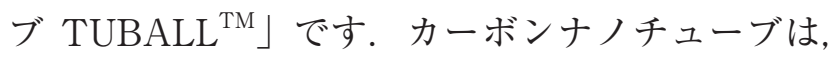
日本人により発見され構造が決定された新素材で 実用化に向けた検討が進んでいます。本報では, その構造や特性, 安全性などの製品開発に役立つ 基本的な情報が述べられています。また，ゴム材料 への適用例としてシリコーンゴムへの導電性付与 やSBRの機械的特性への影響が紹介されています.

最後は「エチレン・材レフンコオリゴマーの 機能性コンパウンドへの応用」と題して, スチレ ン系熱可塑性エラストマーに対するエチレン・ $\alpha$ オ レフィンコオリゴマーの改質効果について紹介い ただきます，従来の改質剤である鉱物油を使用し た場合の効果と比較され, 小角 X線散乱測定や透 過型電子顕微鏡観察を行い, 明らかになった鉱物 油とオリゴマーの分散構造の違いがまとめられて います。

6月号および8月号で企画した特集号が，ゴム産 業に従事されている会員の皆様のニーズに応えら れ, 新製品・技術の開発にお役に立てれば幸いです。 最後になりましたが，本特集号に原稿をお寄せい ただきました著者の方々に厚くお礼申し上げます。 （編集委員会・特集企画担当 曽根 卓男） 